\title{
On the Unequal Inequality of Poor Communities
}

\author{
Chris Elbers, Peter F. Lanjouw, Johan A. Mistiaen, Berk Özler and Ken Simler*
}

February 5, 2004

\begin{abstract}
Important differences exist between communities with respect to their needs, capacities and circumstances. As central governments are not able to discern these differences fully, they seek to achieve their policy objectives by relying on decentralized mechanisms that utilize local information. However, household and individual characteristics within communities can also vary substantially. A growing theoretical literature suggests that inequality within communities can influence policy outcomes, and that this influence could be harmful or helpful, depending on the circumstances. Empirical investigations into the impact of inequality have, to date, largely been held back by a lack of systematic evidence on community-level inequality. This paper uses household survey and population census data to estimate per capita consumption inequality within communities in three developing countries: Ecuador, Madagascar, and Mozambique. Communities are found to vary markedly from one another in terms of the degree of inequality they exhibit. We also show that there should be no presumption that inequality is less severe in poor communities. We argue that the kind of community-level inequality estimates generated in this paper can be utilized in designing and evaluating decentralized anti-poverty programs.
\end{abstract}

Key Words: Inequality, targeting.

JEL Classification Numbers: D63, H70, I38, R13

* Elbers is with Vrije (Free) University Amsterdam, Lanjouw, Mistiaen and Özler are with the World Bank, and Simler is with the International Food Policy Research Institute. We are grateful to Francois Bourguignon, Francisco Ferreira, Emanuela Galasso, Ravi Kanbur, Jenny Lanjouw, Vijayendra Rao, Martin Ravallion and two anonymous referees for comments and/or useful discussions. All errors are our own. The views presented here should not be taken to reflect those of the World Bank or affiliated institutions. Correspondence: planjouw @ worldbank.org. 



\section{Introduction}

Governments in developing countries commonly implement decentralized antipoverty programs that are designed to distribute assets or cash to individuals or households. In many such cases, the central government first distributes its poverty reduction budget to communities, and these are then left to decide how to allocate that budget across individuals. Social Funds projects provide a well-known example from the family of community based development (CBD) initiatives, in which poor communities are required to identify, apply for funding, design, implement and manage their projects (Mansuri and Rao, 2003). ${ }^{1}$ These initiatives aim to improve poverty targeting and implementation of projects by making use of information at the local level and by involving local participation. However, in practice these potential benefits may be outweighed by the possibility of resources being captured by local elites. ${ }^{2}$ For example, in their review of the CBD approach, Mansuri and Rao (2003) argue that while potential gains from $\mathrm{CBD}$ efforts are large, there are also important risks inherent in the basic precepts of the approach.

Uncertainty around the ultimate impact of such programs implies that a blanket application of a given approach in all communities may not be appropriate. Again, Mansuri and Rao (2003) caution against the wholesale scaling-up of best-practices identified in one, or perhaps several, pilot settings, as the success of such pilot projects might depend crucially on local conditions that are not observed elsewhere. At the same time, it is clear that administrators of large projects, such as a country-wide cash transfer or Social Funds program, are unable to take into account the full range of local characteristics that could

\footnotetext{
${ }^{1}$ Mansuri and Rao (2003) distinguish CBD from Community Driven Development (CDD), popularized by the World Bank, in that the latter refer to projects where communities have direct control over key project decisions as well as the management of investment funds. CBD can be thought of as a broader umbrella term that accommodates but is not restricted to the World Bank's CDD concept.
} 
possibly affect project performance. Hence, policymakers are confronted with the challenging task of designing schemes that do take critical local information into account, but are not prohibitively costly in terms of their implementation.

One way governments have traditionally broached this problem is to categorize communities by easily observable characteristics and then adapt schemes for different groups. For example, while local level data on poverty are generally unavailable, government programs often draw on proxy indicators - believed to be correlated with local poverty conditions - to determine eligibility of communities for various projects. As we discuss below, there is emerging theoretical analysis and empirical evidence that suggests that local inequality may also affect local development outcomes. However, such information has not generally made its way into program design. There seem to be two main reasons why local inequality is not explicitly considered in program design. First, until recently estimates of local inequality measures have not been widely available. While basic needs-type indices have been used in place of the missing income (or expenditure) poverty measure, such proxies have not been available for income inequality. ${ }^{3}$ Second, when the target of an intervention is a small, poor community, inequality may not be considered of primary importance: it seems natural to assume that in the poorest communities in the developing world livelihoods are at the subsistence level and so there is little scope for pronounced variation in wellbeing across households and individuals.

This paper addresses these two issues. First, using data from Ecuador, Madagascar, and Mozambique, we apply a newly developed methodology to estimate local-level welfare

\footnotetext{
${ }^{2}$ A vivid illustration of elite capture problems in practice and a theoretical treatment of this issue are provided in Platteau and Gaspart (2003).

${ }^{3}$ McKenzie (2003) provides a recent attempt to proxy local inequality on the basis of easily observed correlates of household income.
} 
outcomes combining the detailed information available from a household survey with the large-scale representation of the population census. We suggest that meaningful estimates of income or expenditure inequality for small areas can be obtained for many countries on the basis of these techniques. Second, we show that there is great heterogeneity in inequality across these communities in each country. We find that this heterogeneity in local inequality levels is still present when we focus our attention on the poorest communities in rural areas. The combined implication of these findings is that information on local inequality is available for use by program implementers and that this information can help to categorize communities even after conditioning on local poverty and type of area.

How Can Local Inequality Affect Welfare Outcomes?

Mansuri and Rao (2003) present a comprehensive overview of the theoretical and empirical literature on the relationship between local inequality and development outcomes. Two critical issues emerge: First, how does inequality within a community influence the targeting impact of a particular project, and second, how does local inequality shape the degree and nature of collective action within communities?

Recent theoretical analysis suggests that inequality may affect targeting outcomes of social funds projects or anti-poverty transfer schemes by reducing the relative power of the intended beneficiaries (Galasso \& Ravallion, 2004; Bardhan and Mookherjee, 1999). The advantage of such decentralized approaches to make use of better community-level information about priorities and the characteristics of residents could be offset by the possibility that the local governing body is controlled by elites - who may have different 
objectives than the poor within their communities. While the predictions from this theoretical work are ambiguous, limited empirical evidence shows that both the pros and the cons of decentralized decision-making are at work in various countries. For example, Alderman (2002) finds in Albania that communities were able to improve targeting by using information unavailable to the central government. On the other hand, Galasso \& Ravallion (2004) find that high levels of local inequality (measured in terms of landholdings) were associated with worse targeting performance under the Food for Education program in Bangladeshi villages.

A detailed case study of the north Indian village of Palanpur provides one illustration of the manner in which local elites are able to appropriate for their own purposes resources and opportunities made available to the community through public provisioning. Drawing on information collected in this small village over the period spanning the late $1950 \mathrm{~s}$ through the early 1990s, Drèze, Lanjouw and Sharma (1998) document the introduction of 18 types of government-provided programs in the village. These include a public works village-road building program, free schooling, free basic health care, old-age pensions, a fair-price shop, a farmer's cooperative, and so on. The sobering diagnosis is that the large majority of these programs were for all practical purposes non-functional, particularly wherever there existed a redistributive component. Drèze, Lanjouw and Sharma (1998) argue that a key explanation for this dispiriting record is that, at the village level, collective institutions were dominated by privileged groups. This means that only those programs that enjoyed strong backing from the politically advantaged segment of the village were allowed to succeed. Drèze, Lanjouw and Sharma (1998) argue that "there is little prospect of major 
improvement in the orientation and achievements of government intervention without a significant change in the balance of political power, both at the state and at the local level". ${ }^{4}$

There is also a rich literature on the relationship between inequality and collective action with implications on the provision of public goods, management of common pool resources, and group participation (Olson, 1973; Balland and Platteau, 1999, 2001, 2003; Dayton-Johnson and Bardhan, 2002, among others). This literature points to the possibility, at least in principle, that some inequality may be necessary in order to mobilize the collective action needed for group provision of a public good (Olson, 1973). The argument is that if a community is large and homogeneous, no single individual could make any significant difference in the provision of the public good, and hence all would want to freeride, resulting in no provision.

Again, the theoretical relationship between inequality, participation and collective action is complex. However, most of the empirical evidence seems to point to a negative or a U-shaped relationship, where increased inequality leads, at least initially, to a decline in collective action (Dayton-Johnson, 2000; Bardhan and Dayton-Johnson (2002), Khwaja (2001); Alesina and La Ferrara (2000), La Ferrara (2002)).

The growing literature on the relationship between local inequality and development outcomes thus suggests that there are a number of ways in which development efforts, such as those described in this paper, could be influenced by local inequality. The empirical literature, while still far from complete, suggests that on balance inequality is likely to hamper local development efforts. It is for this reason that incorporating information on

\footnotetext{
${ }^{4}$ The review by Drèze, Lanjouw and Sharma (1998) does not cover any specific CBD projects in Palanpur. It is possible that performance of such projects might have been different. The review does indicate, however, that any notion of the villagers in Palanpur all having the same objectives, interests, and influence would be sorely mistaken. That villagers differed in terms of economic well-being was clearly discernable in the study:
} 
inequality into the design of development efforts might be necessary. This paper argues that such information can be obtained with data available in many developing countries.

In the next section we describe the methodology underlying the estimation of local welfare indicators and our data, and section 3 discusses the plausibility and the precision of our inequality estimates in Ecuador, Madagascar, and Mozambique. In section 4, we examine the importance of local-level inequality by decomposing national inequality in each of the three countries into a within-community and between-community component. Also in this section, we argue that this decomposition exercise produces a summary statistic that masks significant heterogeneity in inequality across communities. In section 5, we provide evidence that this heterogeneity in inequality is evident even among poor rural communities. Section 6 discusses implications for policy.

\section{Data and Methodology}

The data used in this study consist of a household survey and a population census from Ecuador, Madagascar, and Mozambique. Table 1 presents the basics on each of the data sources, such as year, sample size, stratification, etc. For more detail on the data, refer to the studies listed in the References row in Table 1.

Construction of comprehensive geographic profiles of inequality across localities has been constrained by the limitations of conventional distributional data. Detailed household surveys, which include reasonable measures of income or consumption, are samples and thus are rarely representative or of sufficient size at low levels of disaggregation to yield statistically reliable estimates. At the same time, census (or large

income inequality within Palanpur was on the same orders of magnitude as measures of inequality for India as a whole (Lanjouw and Stern, 1998). 
sample survey) data of sufficient size to allow disaggregation either have no information about income or consumption, or measure these variables poorly. ${ }^{5}$

Using a recently developed statistical procedure to combine data sources so as to take advantage of the detailed information available in household sample surveys and the comprehensive coverage of a census, this paper provides estimates of inequality at a level of disaggregation previously unattainable in each of the three countries. The methodology is developed in detail by Elbers, Lanjouw and Lanjouw (2002 and 2003a), and applications are described in a series of papers (Demombynes et. al., 2002, Elbers et. al., 2002, and Mistiaen et. al., 2002 among others), so we provide only the briefest description here.

First a model of log per capita household expenditures, $y$, is estimated using the sample survey data, restricting the explanatory variables to those either common to both the survey and the census, or variables in a tertiary dataset that can be linked to both of those data sets. ${ }^{6}$ Then, letting $W$ represent an indicator of poverty or inequality, we estimate the expected level of $W$ given the census-based observable characteristics of the population of interest using parameter estimates from the 'first-stage' model of $y$. The same approach could be used with other household measures of wellbeing, such as assets, income, or employment.

The first-stage estimation is carried out using the household sample survey. Our first concern is to develop an accurate empirical model of household consumption. Consider the following model:

$$
\ln y_{c h}=E\left[\ln y_{c h} \mid x_{c h}^{T}\right]+u_{c h} \approx x_{c h}^{T} \boldsymbol{\beta}+\eta_{c}+\varepsilon_{c h},
$$

\footnotetext{
${ }^{5}$ See Alderman et al. (2003)

${ }^{6}$ As described in Elbers et. al (2003a), a separate model is estimated for each stratum, rather than forcing the models and the parameter estimates to be the same for the whole country.
} 
where household $h$ is located in sample cluster $c, \eta$ and $\varepsilon$ are uncorrelated with each other and are uncorrelated with observables. This specification allows for an intracluster correlation in the disturbances. For any given disturbance variance, $\sigma_{c h}^{2}$, the greater the fraction due to the common component $\eta_{c}$, the less one benefits from aggregating over more households. Welfare estimates become less precise. Further, failing to account for spatial correlation in the disturbances could bias the inequality estimates.

A Hausman test described in Deaton (1997) is used to determine whether to estimate with household weights. $\bar{R}^{2}$ 's for our models are generally high, ranging between 0.45 and 0.77 in Ecuador, 0.29 to 0.63 in Madagascar, and 0.27 to 0.55 in $^{\text {Mozambique. }}{ }^{7}$

We next model the variance of the idiosyncratic part of the disturbance, $\sigma_{\varepsilon, c h}^{2}$. To model heteroskedasticity in the household-specific part of the residual, we choose between 5 and 20 variables, $\mathbf{z}_{c h}$, that best explain variation in $e_{c h}^{2}$ out of all potential explanatory variables, their squares, and interactions. ${ }^{8}$

Finally, we determine the distribution of $\eta$ and $\varepsilon$ using the cluster residuals $\hat{\eta}_{c}$ and standardized household residuals. We use normal or $t$ distributions with varying degrees of freedom, or the actual standardized residual distribution mentioned above when taking a semi-parametric approach. Before proceeding to simulation, the estimated variancecovariance matrix is used to obtain final GLS estimates of the first stage consumption model.

At this point we have a full model of consumption that can be used to simulate any expected welfare measures with associated prediction errors.

\footnotetext{
${ }^{7}$ Again, see Elbers et al. (2002), Mistiaen et al. (2002) and Simler and Nhate (2002) for details.
} 


\section{Estimates of Local Inequality in Three Countries}

In this section, we examine how our census-based estimates compare with estimates from the countries' respective surveys at the level at which those surveys are representative. ${ }^{9}$ If the methodology we employ is applied properly, with proper attention to data comparability issues, first-stage regression models and the error structures used in simulating the inequality measures, then stratum level estimates should naturally correspond closely to those in the household survey.

Table 2 presents estimates of average per capita consumption for each country from both the household survey and census at the stratum level, for which the household survey is representative. Indeed, in nearly every case we cannot reject that estimates of average per capita consumption across the two data sources are the same (at the 95\% confidence level). With few exceptions point estimates match closely. Note that the standard errors of the per capita consumption estimates in the census are almost always smaller than those in the household survey. While the census estimates are predicted with error mainly due to the imprecision of the first-stage regressions, they are free of sampling error, making them more precise than their counterparts from the household survey.

Comparing stratum-level estimates of inequality across the census and survey is less straightforward. Inequality measures tend to be sensitive to the tails in the distribution of expenditure. Since far-off portions of the tails are typically not observed in the survey (because of its small sample size), the survey estimates of inequality will often be below the true level of inequality. Perhaps more importantly, non-response may be of some

\footnotetext{
${ }^{8}$ We limit the number of explanatory variables to be cautious about over-fitting and use a bounded logistic functional form.
} 
importance in a household survey, and to the extent that non-response can be expected to be more prevalent among rich households, the resulting selection bias will lead to further downward bias of survey-based estimates. ${ }^{10}$ To the extent that a census suffers less from such problems of observation, and assuming that the expenditure model is correct, the expenditure of rich households will be better represented in the census-based estimates of inequality. These considerations lead one to expect higher inequality estimates from censusbases imputation.

Table 3 presents estimates of the Gini-coefficient in our three countries. Standard errors are presented for all estimates - reflecting the complex sample design of the household survey for the survey-based estimates, and our imputation procedure for the census based estimates. For Ecuador and Mozambique, we can see that the census estimates of consumption inequality tend to be higher than the survey based estimates, although not generally to such an extent that one can reject that they are the same (Table 3). ${ }^{11}$ Note that for some provinces in Mozambique, such as Sofala, Maputo Province and Maputo City, the estimates from the census are not only higher than those in the survey, but also happen to be quite imprecisely estimated. ${ }^{12}$

In Madagascar, it is the standard errors on the survey estimates of inequality that are quite high (Table 3). This serves as a reminder that although stratum-level estimates of welfare in household surveys are often referred to as representative, the sample size in these strata can be rather small so that the accompanying welfare estimates are not always precise.

\footnotetext{
${ }^{9}$ For a similar analysis, focusing specifically on poverty, see Demombynes et al (2002).

${ }^{10}$ On this, see also Mistiaen and Ravallion (2003).

11 These issues are subject of current research. If anything we expect the true difference between census-based and survey-based inequality estimates to be even larger, since in the simulations underlying poverty maps we regularly discard extreme draws of the error terms. Again, this might lead to an under-representation of highexpenditure cases.
} 
Nonetheless, for our purposes it is encouraging to note that point estimates of the Gini coefficient between the survey and the census in Madagascar are often quite close.

Elbers, Lanjouw and Lanjouw (2002, 2003a) demonstrate that standard errors on census-based estimates are inversely correlated with the size of the target population. Thus, although they may look good at the stratum level, estimates of inequality for smaller localities could become quite imprecise. Does this imply that at fine levels of disaggregation - such as firaisana in Madagascar, or parroquia or zona in Ecuador - our inequality estimates are too noisy to be useful? In the three countries we are working with here, we have produced estimates of inequality at the third administrative level (the firaisana in Madagascar, the parroquia in rural Ecuador, the administrative post in Mozambique). Elbers et al (2002) document that standard errors correspond to about 5-15\% of point estimates of inequality for these localities (see also below). This is in the same range of what is generally judged to be acceptable at the stratum level in household surveys. Elbers et al (2002) also show that the explanatory power of simple descriptive OLS regressions of inequality at the smallest administrative level on a set of simple community characteristics is quite high in these three countries $\left(\mathrm{R}^{2}\right.$ 's ranging between 0.57 and 0.78 in urban areas and between 0.38 and 0.57 in rural areas). If the inequality estimates produced with this methodology were just noise, one would expect the explanatory power of these regressions to be much lower. ${ }^{13}$

Based on the evidence presented in this section, we conclude that the estimation technique used here can yield meaningful estimates of inequality for small areas. Next, we

\footnotetext{
${ }^{12}$ Fortunately, as we shall see below, there is no evidence that the census-based estimates become even noisier at lower levels of aggregation in Mozambique.
} 
focus our attention on inequality decompositions by administrative units and the heterogeneity of inequality across communities.

\section{Decomposing inequality by geographic sub-groups}

We now turn to inequality decomposition by geographic sub-unit, which enjoys a long tradition in the empirical analysis of inequality, in both developed and developing countries. It is clear that when national inequality is attributable largely to differences in mean incomes across localities, the policy implications may be quite different from the situation, where sub-regions themselves are unequal and national inequality is basically an expression of heterogeneity that already exists at the local levels. We decompose inequality using the General Entropy class of inequality measures, a class of measures that is particularly well suited for this exercise. ${ }^{14}$ This class of measures takes the following form:

$$
\begin{array}{lr}
G E_{c}=\frac{1}{c(c-1)} \sum_{i} f_{i}\left[\left(\frac{y_{i}}{\mu}\right)^{c}-1\right] & \text { for } \mathrm{c} \neq 0,1 \\
=-\sum_{i} f_{i} \log \left(\frac{y_{i}}{\mu}\right) & \text { for } \mathrm{c}=0 \\
=\sum_{i} f_{i}\left(\frac{y_{i}}{\mu}\right) \log \left(\frac{y_{i}}{\mu}\right) & \text { for } \mathrm{c}=1
\end{array}
$$

\footnotetext{
${ }^{13}$ Elbers, Lanjouw and Lanjouw (2003b) argue that although the inequality measures included in these regressions have been estimated, this does not invalidate their use for these purposes (although they do advocate correcting standard errors for model error).

${ }^{14}$ Following Bourguignon (1979), Shorrocks (1980) and Cowell (1980). Cowell (2000) provides a useful recent survey of methods of inequality measurement, including a discussion of the various approaches to subgroup decomposition. Sen and Foster (1997) and Kanbur (2000) discuss some of the difficulties in interpreting results from such decompositions.
} 
where $f_{i}$ is the population share of household $i, y_{i}$ is per capita consumption of household $i$, $\mu$ is average per capita consumption, and $c$ is a parameter that is to be selected by the user. ${ }^{15}$ This class of inequality measures can be decomposed into a between and within-group component along the following lines:

$$
\begin{array}{ll}
G E_{c}=\frac{1}{c(c-1)}\left[1-\sum_{j} g_{j}\left(\frac{\mu_{j}}{\mu}\right)^{c}\right]+\sum_{j} G E_{j} g_{j}\left(\frac{\mu_{j}}{\mu}\right)^{c} & \text { for } \mathrm{c} \neq 0,1 \\
G E_{c}=\left[\sum_{j} g_{j} \log \left(\frac{\mu}{\mu_{j}}\right)\right]+\sum_{j} G E_{j} g_{j} & \text { for } \mathrm{c}=0 \\
G E_{c}=\left[\sum_{j} g_{j}\left(\frac{\mu_{j}}{\mu}\right) \log \left(\frac{\mu_{j}}{\mu}\right)\right]+\sum_{j} G E_{j} g_{j}\left(\frac{\mu_{j}}{\mu}\right) & \text { for } \mathrm{c}=1
\end{array}
$$

where $j$ refers to sub-groups, $g_{j}$ refers to the population share of group $j$ and $\mathrm{GE}_{j}$ refers to inequality in group $j$. The between-group component of inequality is captured by the first term to the right of the equality sign. It can be interpreted as measuring what would be the level of inequality in the population if everyone within the group had the same (the groupaverage) consumption level $\mu_{j}$. The second term on the right reflects within-group inequality, or what would be the overall inequality level if there were no differences in mean consumption across groups but each group had its actual within-group inequality $\mathrm{GE}_{j}$. Ratios of the respective components with the overall inequality level provide a measure of the percentage contribution of between-group and within-group inequality to total inequality.

\footnotetext{
${ }^{15}$ Lower values of $c$ are associated with greater sensitivity to inequality amongst the poor, and higher values of c place more weight to inequality among the rich. A $c$ value of 1 yields the well known Theil entropy measure, a value of 0 provides the Theil $\mathrm{L}$ or mean $\log$ deviation, and a value of 2 is ordinally equivalent to the squared coefficient of variation.
} 
In Table 4, we present the decomposition results in each of the three countries examined in this paper. At one extreme, when inequality is measured at the national level, all inequality is, by definition, within-group. At the other extreme, when each individual household is taken as a separate group, the within-group contribution to overall inequality is zero and all inequality is between-group. But where does the between-group component start to outweigh the within-group component? Is it reasonable to suppose that at a sufficiently low level of disaggregation, such as a village or community, inequality within groups is small, and most of overall inequality is due to differences between groups?

The first row for each country in Table 4 contains the share of inequality within and between communities, where community is defined as the third administrative level (number of households ranging between 1,000-10,000) in each of our three countries. The inequality measure we use is the mean log deviation, i.e. $\mathrm{GE}(0) .{ }^{16}$ The highest betweengroup inequality is observed in Ecuador, at approximately 41\%. In Madagascar and Mozambique, the share of inequality that can be attributed to mean expenditure differences between communities is much smaller, at $25 \%$ and $22 \%$, respectively. There is also evidence, particularly in Ecuador, that the observed between-community inequality is due mainly to the differences between urban and rural communities. When we focus our attention solely on rural communities in Ecuador, the between-group component of inequality falls to under $15 \%$ of total inequality in rural Ecuador. Similarly in Madagascar, the share of between-group inequality in rural areas is $18 \%$, significantly lower than for the combined rural and urban areas. In all three countries, overall inequality is mostly

\footnotetext{
${ }^{16}$ Results remain virtually identical for other values of $c$.
} 
attributable to inequality within communities, even when the community is defined as the lowest level of central government administrative unit. ${ }^{17} 18$

Interpretations of decompositions such as these are, however, not completely straightforward. For example, the above decomposition results (documenting a large within-group component) do not imply that local inequality levels are uniformly high, or even that the majority of communities exhibit high levels of inequality. It is important to recognize that the decomposition provides a summary statistic, suggesting that on average within-group inequality is not particularly low at the third administrative level. In other words, it is perfectly possible that a country is characterized by both highly equal and highly unequal communities. A simple example can illustrate this. Consider a population of 8 individuals with consumption values $(1,1,2,2,4,4,5,5)$. This population could be divided into two communities as $(1,2,4,5)$ and $(1,2,4,5)$; or as $(1,1,5,5)$ and $(2,2,4,4)$. In both cases the two communities have the same average consumption. As a result the between-group component from a decomposition exercise as has been carried out above is always zero (and the within-group share is thus $100 \%$ in both cases). However, in the first case inequality in the two communities is exactly equal to national inequality, whereas in the second case one community has a higher and the other a lower

\footnotetext{
${ }^{17}$ Inequality estimates produced on the basis of the methodology described in section 2 are averages calculated over a number of simulations (100 in our case). It is possible that a decomposition of inequality carried out after this averaging procedure has occurred overstates the within-group component of inequality because differences in inequality across communities have been smoothed out. To check this we carried out the decomposition exercise for each of the 100 simulations and then averaged across the decomposition results. We found that the between group component of inequality increased by at most $1-2 \%$ and that our qualititative results were completely unchanged.

${ }^{18}$ We have no other reason to suspect that our methodology for estimating local level inequality is associated with any built-in tendency to over state within-group inequality. One way to test this is to carry out the imputation exercise described here into a dataset that also contains information on welfare that has been directly collected, and to then compare decomposition results on the basis of imputed welfare against those on the basis of observed welfare. Elbers, Lanjouw, Lanjouw and Leite (2003) undertake such an analysis in Brazil and show that a decomposition of inequality based on imputed consumption reaches virtually identical conclusions as a decomposition based on observed income.
} 
level of inequality than at the national level. Hence, finding a high within-group share from a decomposition exercise across a large number of communities is perfectly consistent with great heterogeneity in inequality levels across those same communities. It is then natural to ask, in our case, whether communities vary widely in their degree of inequality.

In Figures 1-5, we plot community-level inequality estimates and compare these with overall inequality. Communities are ranked from most equal to most unequal, and 95\% confidence intervals on each community-level estimate are included as scatter plots. Figure 1 compares parroquia level inequality in rural Ecuador against the overall inequality level in rural areas. We see that although the within-group share from the decomposition was as high as $86 \%$, this summary statistic masks considerable variation in parroquia inequality levels. A large majority of parroquia-level point estimates are well below the national level in rural Ecuador. Even allowing for the imprecision around the parroquia-level estimates (which are typically $5-15 \%$ of the point estimate), a sizeable proportion of parroquias are unambiguously more equal than the picture at the national level. Another sizeable proportion is not obviously less or more unequal than the country as a whole, and a smaller number of parroquias are considerably more unequal. ${ }^{19}$ In urban Ecuador (Figure 2), the proportion of zonas that have lower inequality than the national-level inequality rate is even higher than in rural areas. The precision of point estimates in urban areas of Ecuador is somewhat higher than in rural areas; accordingly, more zonas lie unambiguously below the national inequality level.

\footnotetext{
${ }^{19}$ Note the reason that there are more communities with inequality below the national level than above the national level is due to the fact that between-group inequality, while relatively small, is not absent. Differences in average per capita consumption ensure that at least some of total inequality is attributable to differences between groups. If there were no within-group inequality at all, or if all communities had the same level of
} 
In rural and urban Madagascar (Figures 3 and 4) and in Mozambique (Figure 5) the picture is very similar. In each of the three countries, there is clearly a sizeable subset of communities with lower inequality than the country as a whole, another large group for which inequality is not significantly different from inequality in the country as a whole, and a small third group of communities with inequality higher than the national level.

\section{Are Poor Communities More Equal than Others?}

In the last section, we noted that while most of the inequality in Ecuador, Madagascar, and Mozambique is attributable to inequality within communities, there is a lot of heterogeneity in inequality across these communities within each country. In this section, we ask whether inequality is less marked if we focus our attention on poor communities. CBD programs are often targeted primarily to poor communities. If those communities have low levels of inequality, it may be less important that policymakers incorporate information on inequality into the design and implementation of $\mathrm{CBD}$ projects. Unfortunately, it turns out that this is not the case for the countries examined in this paper.

Figures 6,8 , and 10 present the range of inequality (measured by the commonly used Gini index) across communities in each country by quintiles of the imputed headcount index (see Demombynes et al, 2003). ${ }^{20}$ The Gini index at the community level ranges from 0.299 to 0.501 in Ecuador, 0.231 to 0.466 in Madagascar, and 0.261 to 0.534 in Mozambique. ${ }^{21}$ Interestingly, in all three countries, median inequality in the poorest quintile

within-group inequality, then overall inequality would be greater than or equal to inequality in each of the individual communities.

${ }^{20}$ It is possible that we would observe high inequality in high poverty areas simply because of the fact that these two measures of welfare are highly correlated. However, the results presented in this section are the same if we rank communities by their mean consumption levels instead of the headcount index.

${ }^{21}$ These reported ranges exclude the top and bottom $1 \%$ of communities (in terms of the Gini index) in each country. 
is not lower than that in any of the richer quintiles. Furthermore, the range of inequality levels across communities is among the widest in the poorest quintile. This observation remains true even when we restrict our attention to rural communities only (Figures $7 \& 9$ ). We conclude that a typical poor community in any of these three countries - even if it is in a rural area - is at least as unequal as other communities, and that the range of inequality among poor communities is not narrower than the country as a whole. The next section discusses the possible policy implications of our findings.

\section{Policy Discussion}

There has been a massive increase in resources devoted to CDD programs in the past 10 years. The review by Mansuri and Rao (2003) suggests that between 1996 and 2003, funding for CDD projects rose from around US\$325 million to around $\$ 2$ billion. While the main goal is to achieve better outcomes by involving local communities in the decisionmaking process and management of projects, governments nonetheless need some basic indicators to target communities and tailor basic features of these projects to different types of communities. So far, governments have commonly utilized type of area (urban/rural) and proxy information on poverty at the community level for such purposes.

In this paper, we propose another measure of welfare, namely inequality at the community level, as a possible additional indicator to inform the design of decentralized anti-poverty programs and CDD projects. Recent theory and limited empirical evidence suggests that inequality may be related to outcomes at the community level. It is possible that inequality at the community level may lead to the capture of the intended benefits by the local elite or inequality may simply be highly correlated with another (not easily observed) 
factor that leads to elite capture. Collective action and the subsequent provision of public goods may also be correlated with the level of inequality within communities.

A recently developed small area estimation technique can provide estimates of inequality at the local level. In the three different countries examined here, we find that although, on average, most of the consumption inequality in each of Ecuador, Madagascar, and Mozambique is attributable to inequality within communities, local inequality varies widely across communities. Furthermore, we find that inequality is highly heterogeneous even in the poorest communities in these countries. Not only is inequality in a typical poor community as high as in other communities, but the range of inequality levels among poor communities is at least as wide as it is in richer communities. This finding remains true even when we restrict our attention to rural areas.

Our findings suggest that local inequality can provide additional information even after controlling for the type of area and the poverty levels of communities. It is possible that use of such information can enhance desired outcomes. For example, for transfer programs where it is intended that local communities identify poor beneficiaries, eligible communities could broadly be categorized as low, middle, and high inequality. Random audits and means-tested targeting by the central government (as are conducted, for example, in Mexico's PROGRESA program) could then be considered to improve pro-poor targeting in the middle and high inequality communities.

Clearly, a first priority is to undertake further and more systematic research into the relationship between local inequality and various development outcomes. A critical question concerns the manner and extent to which current development processes and practices interact with local inequality. Better estimates of local level consumption 
inequality made possible through application of the techniques described in section 2 of this paper, as well as through other related approaches, offer important new opportunities for analysis. At present, micro-level estimation of welfare based on the methodology described here has been completed or is currently underway in some 25 developing countries. Such estimates can be combined with detailed information on the operation of anti-poverty programs and CBD projects in these countries, with an eye toward uncovering systematic relationships, positive or negative. 


\section{References}

Alderman, H. (2002) 'Do Local Officials Know Something We Don't? Decentralization of Targeted Transfers in Albania', Journal of Public Economics, Vol 83, 375-404.

Alesina, A. and La Ferrara, E. (2000) 'Participation in Heterogeneous Communities' Quarterly Journal of Economics, pg 847-904.

Baland, J-M. and Platteau, J-Ph (1999) 'The Ambiguous Impact of Inequality on Local Resource Management', World Development, Vol 27, No. 5.

Baland, J-M and Platteau, J-Ph (2001) 'Collective Action and the Commons: The Role of Inequality' forthcoming in, Baland, J-M, Bardhan, P. and Bowles, S.(eds) Inequality, Cooperation and Environmental Sustainability (Princeton: Princeton University Press).

Baland, J-M and Platteau, J-Ph (2003) 'Institutions and the Efficient Management of Environmental Resources', in Mahler, K.G. and Vincent, J.R. (eds) Handbook of Environmental Economics Vol 1, (Amsterdam: Elsevier North Holland).

Bardhan, P. and Mookherjee, D. (1999) 'Relative Capture of Local and Central Governments', mimeo. Boston University.

Bourguignon, F. (1979) 'Decomposable Income Inequality Measures' Econometrica 47:901-920

Cowell, F. (1980) 'On the Stucture of Additive Inequality Measures' Review of Economic Studies, 47521-531.

Cowell, F. (2000) 'Measurement of Inequality' in Atkinson, A.B. and Bourguignon, F. (eds) (2000) Handbook of Income Distribution Vol. 1, (North Holland: Elsevier Science B.V.)

Dayton-Johnson, J. (2000) 'Determinants of Collective Action on the Local Commons: A Model with Evidence from Mexico', Journal of Development Economics, Vol. 62, 181-208.

Dayton-Johnson, J. and Bardhan, P. (2002) 'Inequality and Conservation on the Local Commons: A Theoretical Exercise’, The Economic Journal, Vo1 112, 577-602.

Deaton, A. (1997) The Analysis of Household Surveys: A Microeconometric Approach to Development Policy. The Johns Hopkins University Press for the World Bank: Washington, D.C.

Demombynes, G., Elbers, C., Lanjouw, J.O., Lanjouw, P., Mistiaen, J. and Özler, B. (2002) 'Producing an Improved Geographic Profile of Poverty: Methodology and Evidence from Three Developing Countries' in van der Hoeven, R. and Shorrocks, A. (eds) Growth, Inequality and Poverty: Prospects for Pro-Poor Economic Development (Oxford: Oxford University Press).

Demombynes, G. and Özler, B. (2002) 'Crime and Local Inequality in South Africa' Journal of Development Economics (forthcoming). 
Drèze, J., Lanjouw, P. and Sharma, N. (1998) 'Economic Development in Palanapur, 1957-1993' in Lanjouw, P. and Stern, N. (eds) Economic Development in Palanpur Over Five Decades (Oxford: Oxford University Press).

Elbers, C., Lanjouw, J.O. and Lanjouw, P. (2003a) 'Micro-Level Estimation of Poverty and Inequality', Econometrica 71(1): 355-64.

Elbers, C., Lanjouw, J.O. and Lanjouw, P. (2003b) 'Imputed Welfare Estimates in Regression Analysis' mimeo, Development Economics Research Group, The World Bank.

Elbers, C., Lanjouw, J.O., Lanjouw, P. and Leite, P. (2003) 'Poverty and Inequality in Brazil: New Estimates from Combined PPV-PNAD Data', paper presented at the Conference on the $100^{\text {th }}$ Anniversary of Jan Tinbergen, Erasmus University, Rotterdam, Netherlands, April 7-11.

Elbers, C., Lanjouw, J.O. and Lanjouw, P. (2002) 'Micro-Level Estimation of Welfare' Policy Research Working Paper 2911, Development Research Group, the World Bank, Washington D.C.

Elbers, C., Lanjouw, P., Mistiaen, J., Özler, B., and Simler, K. (2002) 'Are Neighbors Equal? Estimating Local Inequality in Three Developing Countries' forthcoming in Spatial Inequality and Development, Ravi Kanbur \& Tony Venables (eds.)

Galasso, E. and Ravallion, M. (2004) 'Decentralized Targeting of an Anti-Poverty Program', Journal of Public Economics (in press).

Hentschel, J. and Lanjouw, P. (1996) 'Constructing an Indicator of Consumption for the Analysis of Poverty: Principles and Illustrations with Reference to Ecuador', LSMS Working Paper No.124, DECRG-World Bank: Washington DC.

Hentschel, J., Lanjouw, J.O., Lanjouw, P., and Poggi, J. (2000) 'Combining Census and Survey Data to Trace the Spatial Dimensions of Poverty: A Case Study of Ecuador', World Bank Economic Review 14(1)147-65.

Khwaja, A. (2001) 'Can Good Projects Succeed in Bad Communities? Collective Action in the Himalayas' mimeo, Harvard University.

La Ferrara, E. (2002) 'Inequality and Participation: Theory and Evidence from Rural Tanzania' Journal of Public Economics, v85, No. 2: 235-73.

Lanjouw, P. and Stern, N. (1998) 'Inequality', in Lanjouw, P. and Stern, N. (eds) Economic Development in Palanpur Over Five Decades (Oxford: Oxford University Press).

Mansuri, G. and Rao, V. (2004) 'Community Based (and Driven) Development: A Review', World Bank Research Observer, (forthcoming)

McKenzie, D. (2003) 'Measuring Inequality with Asset Indicators' BREAD Working Paper No. 042, August 2003. 
Mistiaen, J., Özler, B., Razafimanantena, T., and Razafindravonona, J. (2002) 'Putting Welfare on the Map in Madagascar'. Africa Region Working Paper Series on. 34.

Olson, M. (1973) The Logic of Collective Action: Public Goods and the Theory of Groups (Cambridge: Harvard University Press).

Platteau, J.P. and Gaspart, F. (2003). The "Elite Capture" Problem in Participatory Development. Working Paper No. 253 - 2003/14. FUNDP, The University of Namur.

Sen, A.K. and Foster, J. (1997) On Economic Inequality: Expanded Edition with Substantial Annexe (Oxford: Oxford University Press).

Shorrocks, A. (1980) 'The Class of Additively Decomposable Inequality Measures' Econometrica 48: 613-625.

Simler, K. and Nhate, V. (2002) 'Poverty, Inequality and Geographic Targeting: Evidence from Small-Area Estimates in Mozambique', mimeo, International Food Policy Research Institute. 
Table 1. Data Summary

Household Survey

Year

Source

Sample Size

References
1994

Encuesta de

Condiciones de Vida (ECV)

4,500 Households

Hentschel and Lanjouw (1996); and

Hentschel, Lanjouw, Lanjouw and Poggi

(2000)

\section{Population Census}

Year

Coverage

1990

About 10 million
Ecuador individuals in 2 million households
Madagascar

1993-4

Enquête Permanente Auprès des Ménages (EPM)

4,508 Households

Mistiaen, Özler,

Razafimanantena and

Razafindravonona (2002)

1993

1997

Mozambique

1996-7

Inquérito Nacional aos Agregados Familiares sobre as Condições de Vida (IAF96)

8,250 Households

Simler and Nhate (2002)

about 11.9 million individuals in 2.4 million households

about 16 million

individuals in 3.6 million households 


\section{Table 2. Comparison of Survey and Census-Based Average Per-Capita}

Consumption Estimates at the Stratum Level

\begin{tabular}{|l|c|c|l|l|l|l|l|l|}
\hline \multicolumn{3}{|c|}{ Ecuador } & \multicolumn{3}{c|}{ Madagascar } & \multicolumn{3}{c|}{ Mozambique } \\
\hline & Sucres per capita & & Francs per capita & & Meticais per capita \\
\hline Stratum & Survey & Census & Stratum & Survey & Census & Stratum & Survey & Census \\
\hline Quito & 126098 & 125702 & Antananarivo & 513818 & 576470 & Niassa & 4660 & 5512 \\
& $(11344)$ & $(8026)$ & Urban & $(48455)$ & $(23944)$ & & $(355)$ & $(484)$ \\
\hline Sierra & 121797 & 122415 & Fianarantsoa & 360635 & 372438 & Cabo & 6392 & 6586 \\
Urban & $(8425)$ & $(4642)$ & Urban & $(42613)$ & $(21878)$ & Delgado & $(416)$ & $(433)$ \\
\hline Sierra & 66531 & 63666 & Toamasina & 445514 & 417823 & Nampula & 5315 & 5547 \\
Rural & $(4067)$ & $(2213)$ & Urban & $(73099)$ & $(15406)$ & & $(287)$ & $(279)$ \\
\hline Guayaquil & 89601 & 77432 & Mahajanga & 613867 & 580775 & Zambezia & 5090 & 5316 \\
& $(5597)$ & $(2508)$ & Urban & $(74092)$ & $(31025)$ & & $(208)$ & $(274)$ \\
\hline Costa & 86956 & 90209 & Toliara & 343111 & 321602 & Tete & 3848 & 4404 \\
Urban & $(3603)$ & $(2391)$ & Urban & $(76621)$ & $(32193)$ & & $(267)$ & $(176)$ \\
\hline Rural & 57619 & 61618 & Antsiranana & 504841 & 693161 & Manica & 6299 & 6334 \\
Costa & $(4477)$ & $(2894)$ & Urban & $(46148)$ & $(93437)$ & & $(741)$ & $(527)$ \\
\hline Oriente & 110064 & 174529 & Antananarivo & 312553 & 324814 & Sofala & 3218 & 4497 \\
Urban & $(9078)$ & $(56115)$ & Rural & $(23174)$ & $(14378)$ & & $(191)$ & $(379)$ \\
\hline Oriente & 47072 & 59549 & Fianarantsoa & 319870 & 251312 & Inhambane & 4215 & 4177 \\
Rural & $(4420)$ & $(3051)$ & Rural & $(45215)$ & $(18091)$ & & $(359)$ & $(134)$ \\
\hline & & & Toamasina & 275943 & 279239 & Gaza & 6024 & 6521 \\
& & & Rural & $(22832)$ & $(15838)$ & & $(356)$ & $(355)$ \\
\hline & & & Mahajanga & 325872 & 321398 & Maputo & 5844 & 8559 \\
& & & Rural & $(30209)$ & $(19385)$ & Province & $(613)$ & $(745)$ \\
\hline & & & Toliara & 233801 & 259537 & Maputo & 8321 & 11442 \\
& & & Rural & $(22174)$ & $(16222)$ & City & $(701)$ & $(4956)$ \\
\hline & & Antsiranana & 486781 & 442431 & & & \\
\hline
\end{tabular}

All household survey estimates are computed using weights that are the product of household survey weights and household size. The census-based estimates are calculated weighting by household size. Standard errors are in parentheses. 
Table 3. Comparison of Survey and Census-Based Inequality Estimates (Gini) at the Stratum Level

\begin{tabular}{|c|c|c|c|c|c|c|c|c|}
\hline \multicolumn{3}{|c|}{ Ecuador } & \multicolumn{3}{|c|}{ Madagascar } & \multicolumn{3}{|c|}{ Mozambique } \\
\hline$\underline{\text { Stratum }}$ & $\begin{array}{c}\text { Gini } \\
\text { (s.e.) } \\
\text { Survey- } \\
\text { Based }\end{array}$ & $\begin{array}{c}\text { Gini } \\
\text { (s.e.) } \\
\text { Census- } \\
\text { Based } \\
\end{array}$ & Stratum & $\begin{array}{c}\text { Gini } \\
\text { (s.e.) } \\
\text { Survey- } \\
\text { Based }\end{array}$ & $\begin{array}{c}\begin{array}{c}\text { Gini } \\
\text { (s.e.) } \\
\text { Census- }\end{array} \\
\text { Based }\end{array}$ & Stratum & $\begin{array}{c}\text { Gini } \\
\text { (s.e.) } \\
\text { Survey- } \\
\text { Based } \\
\end{array}$ & $\begin{array}{c}\text { Gini } \\
\text { (s.e.) } \\
\text { Census- } \\
\text { Based }\end{array}$ \\
\hline Quito & $\begin{array}{c}0.490 \\
(0.023)\end{array}$ & $\begin{array}{c}0.465 \\
(0.012)\end{array}$ & $\begin{array}{l}\text { Antananarivo } \\
\text { Urban }\end{array}$ & $\begin{array}{c}0.492 \\
(0.027)\end{array}$ & $\begin{array}{c}0.469 \\
(0.012)\end{array}$ & Niassa & $\begin{array}{c}0.355 \\
(0.020)\end{array}$ & $\begin{array}{c}0.402 \\
(0.025)\end{array}$ \\
\hline $\begin{array}{l}\text { Sierra } \\
\text { Urban }\end{array}$ & $\begin{array}{c}0.436 \\
(0.020)\end{array}$ & $\begin{array}{c}0.434 \\
(0.011)\end{array}$ & $\begin{array}{l}\text { Fianarantsoa } \\
\text { Urban }\end{array}$ & $\begin{array}{c}0.430 \\
(0.038)\end{array}$ & $\begin{array}{c}0.426 \\
(0.015)\end{array}$ & $\begin{array}{l}\text { Cabo } \\
\text { Delgado }\end{array}$ & $\begin{array}{c}0.370 \\
(0.025)\end{array}$ & $\begin{array}{c}0.413 \\
(0.021)\end{array}$ \\
\hline $\begin{array}{l}\text { Sierra } \\
\text { Rural }\end{array}$ & $\begin{array}{c}0.393 \\
(0.034)\end{array}$ & $\begin{array}{c}0.457 \\
(0.013)\end{array}$ & $\begin{array}{l}\text { Toamasina } \\
\text { Urban }\end{array}$ & $\begin{array}{c}0.434 \\
(0.042)\end{array}$ & $\begin{array}{c}0.402 \\
(0.015)\end{array}$ & Nampula & $\begin{array}{c}0.391 \\
(0.026)\end{array}$ & $\begin{array}{c}0.400 \\
(0.020)\end{array}$ \\
\hline Guayaquil & $\begin{array}{c}0.378 \\
(0.014)\end{array}$ & $\begin{array}{c}0.416 \\
(0.011)\end{array}$ & $\begin{array}{l}\text { Mahajanga } \\
\text { Urban }\end{array}$ & $\begin{array}{c}0.371 \\
(0.027)\end{array}$ & $\begin{array}{c}0.392 \\
(0.016)\end{array}$ & Zambezia & $\begin{array}{c}0.324 \\
(0.017)\end{array}$ & $\begin{array}{c}0.366 \\
(0.012)\end{array}$ \\
\hline $\begin{array}{l}\text { Costa } \\
\text { Urban }\end{array}$ & $\begin{array}{c}0.359 \\
(0.015)\end{array}$ & $\begin{array}{c}0.382 \\
(0.011)\end{array}$ & $\begin{array}{l}\text { Toliara } \\
\text { Urban }\end{array}$ & $\begin{array}{c}0.514 \\
(0.052)\end{array}$ & $\begin{array}{c}0.504 \\
(0.030)\end{array}$ & Tete & $\begin{array}{c}0.346 \\
(0.019)\end{array}$ & $\begin{array}{c}0.394 \\
(0.018)\end{array}$ \\
\hline $\begin{array}{l}\text { Rural } \\
\text { Costa }\end{array}$ & $\begin{array}{c}0.346 \\
(0.036)\end{array}$ & $\begin{array}{c}0.400 \\
(0.015)\end{array}$ & $\begin{array}{l}\text { Antsiranana } \\
\text { Urban }\end{array}$ & $\begin{array}{c}0.362 \\
(0.025)\end{array}$ & $\begin{array}{c}0.433 \\
(0.039)\end{array}$ & Manica & $\begin{array}{c}0.413 \\
(0.036)\end{array}$ & $\begin{array}{c}0.449 \\
(0.020)\end{array}$ \\
\hline $\begin{array}{l}\text { Oriente } \\
\text { Urban }\end{array}$ & $\begin{array}{c}0.398 \\
(0.035)\end{array}$ & $\begin{array}{c}0.563 \\
(0.104)\end{array}$ & $\begin{array}{l}\text { Antananarivo } \\
\text { Rural }\end{array}$ & $\begin{array}{c}0.376 \\
(0.023)\end{array}$ & $\begin{array}{c}0.404 \\
(0.015)\end{array}$ & Sofala & $\begin{array}{c}0.405 \\
(0.031)\end{array}$ & $\begin{array}{c}0.529 \\
(0.032)\end{array}$ \\
\hline \multirow[t]{5}{*}{$\begin{array}{l}\text { Oriente } \\
\text { Rural }\end{array}$} & $\begin{array}{c}0.431 \\
(0.034)\end{array}$ & $\begin{array}{c}0.478 \\
(0.014)\end{array}$ & $\begin{array}{l}\text { Fianarantsoa } \\
\text { Rural }\end{array}$ & $\begin{array}{c}0.470 \\
(0.050)\end{array}$ & $\begin{array}{c}0.437 \\
(0.018)\end{array}$ & Inhambane & $\begin{array}{c}0.382 \\
(0.037)\end{array}$ & $\begin{array}{c}0.398 \\
(0.012)\end{array}$ \\
\hline & & & $\begin{array}{l}\text { Toamasina } \\
\text { Rural }\end{array}$ & $\begin{array}{c}0.352 \\
(0.036)\end{array}$ & $\begin{array}{c}0.362 \\
(0.017)\end{array}$ & Gaza & $\begin{array}{c}0.380 \\
(0.024)\end{array}$ & $\begin{array}{c}0.421 \\
(0.023)\end{array}$ \\
\hline & & & $\begin{array}{l}\text { Mahajanga } \\
\text { Rural }\end{array}$ & $\begin{array}{c}0.320 \\
(0.026)\end{array}$ & $\begin{array}{c}0.306 \\
(0.015)\end{array}$ & $\begin{array}{l}\text { Maputo } \\
\text { Province }\end{array}$ & $\begin{array}{c}0.424 \\
(0.029)\end{array}$ & $\begin{array}{c}0.518 \\
(0.029)\end{array}$ \\
\hline & & & $\begin{array}{l}\text { Toliara } \\
\text { Rural }\end{array}$ & $\begin{array}{c}0.383 \\
(0.029)\end{array}$ & $\begin{array}{c}0.377 \\
(0.017)\end{array}$ & $\begin{array}{l}\text { Maputo } \\
\text { City }\end{array}$ & $\begin{array}{c}0.444 \\
(0.033)\end{array}$ & $\begin{array}{c}0.560 \\
(0.108)\end{array}$ \\
\hline & & & $\begin{array}{l}\text { Antsiranana } \\
\text { Rural }\end{array}$ & $\begin{array}{c}0.518 \\
(0.110)\end{array}$ & $\begin{array}{c}0.453 \\
(0.048)\end{array}$ & & & \\
\hline
\end{tabular}

All household survey estimates are computed using weights that are the product of household survey weights and household size. The census-based estimates are calculated weighting by household size. Standard errors are in parentheses. 


\section{Table 4. Decomposition of Inequality Between and Within Communities}

\begin{tabular}{lccc}
$\begin{array}{l}\text { Level of } \\
\text { Decomposition }\end{array}$ & $\begin{array}{c}\text { Number of } \\
\text { Sub-Groups }\end{array}$ & $\begin{array}{c}\text { Within-group } \\
\text { inequality }(\%)\end{array}$ & $\begin{array}{c}\text { Between-group } \\
\text { inequality }(\%)\end{array}$ \\
\hline $\begin{array}{r}\text { Ecuador } \\
\text { All Communities }\end{array}$ & 1579 & & 41.2 \\
Urban & 664 & 58.8 & 23.3 \\
Rural & 915 & 76.7 & 14.1 \\
Madagascar & & 85.9 & 25.4 \\
All Communities & 1248 & & 23.2 \\
Urban & 131 & 74.6 & 18.1 \\
Rural & 1117 & 76.7 & \\
Mozambique & & 81.9 & 22.0 \\
All Communities & 424 & & 78.0 \\
\end{tabular}

Our communities in Ecuador are Zonas in urban areas and Parroquias in rural areas.

Communities are Firiasana (communes) in Madagascar and Administrative Posts in Mozambique. 


\section{Figure 1}

RURAL ECUADOR: Distribution Across Parroquias of Parroquia-level Inequality: GE(O) (915 Parroquias; average number of househalds per parroquia: 1050)

(Scatter Plot of $95 \%$ Confidence Intervals)

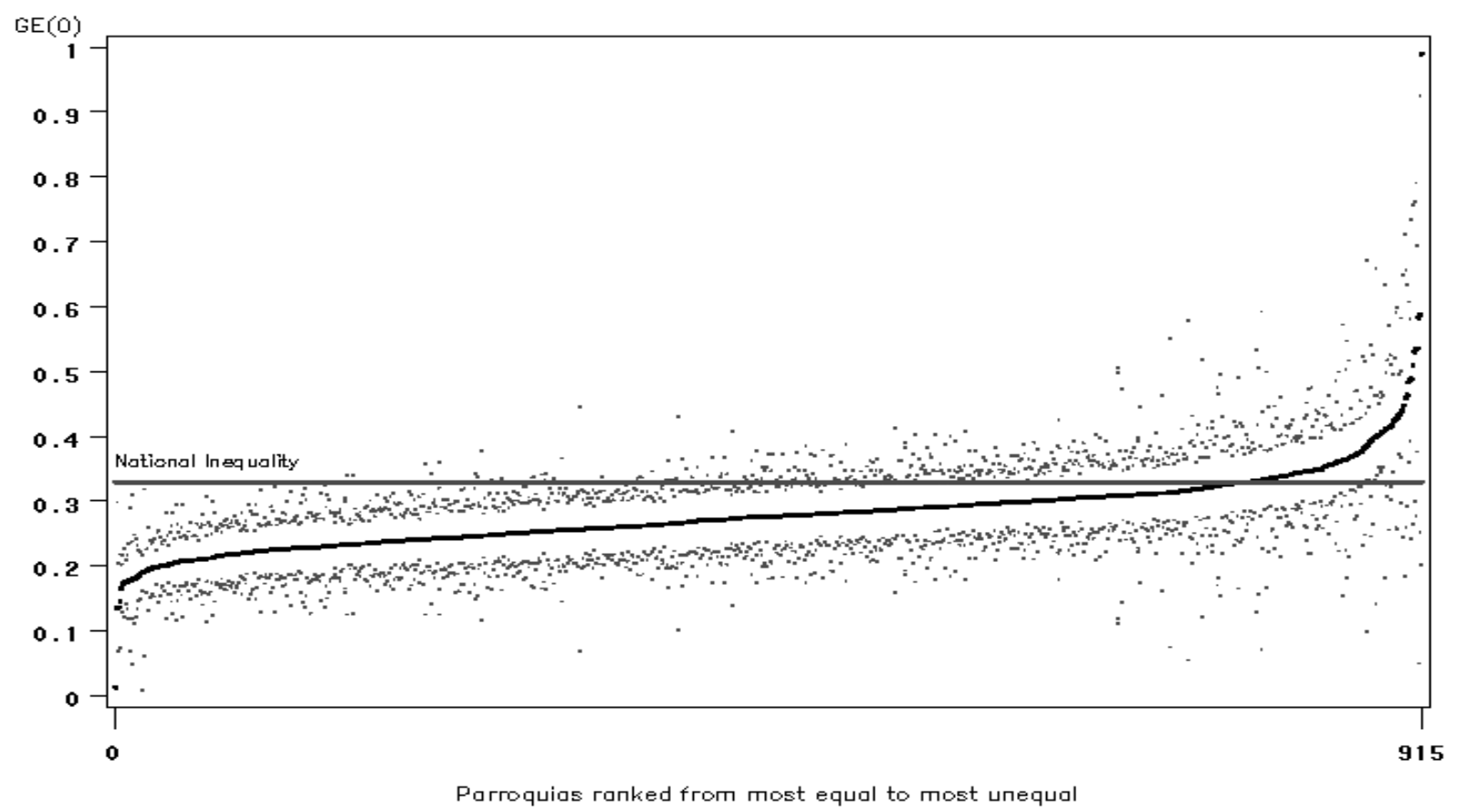

\section{Figure 2}

URBAN ECUADOR: Distribution Across Zonas of Zona-level Inequality: GE(O) (664 Zonas; average number of households per zona: 1325) (Scatter Plot of $95 \%$ Confidence Intervals)

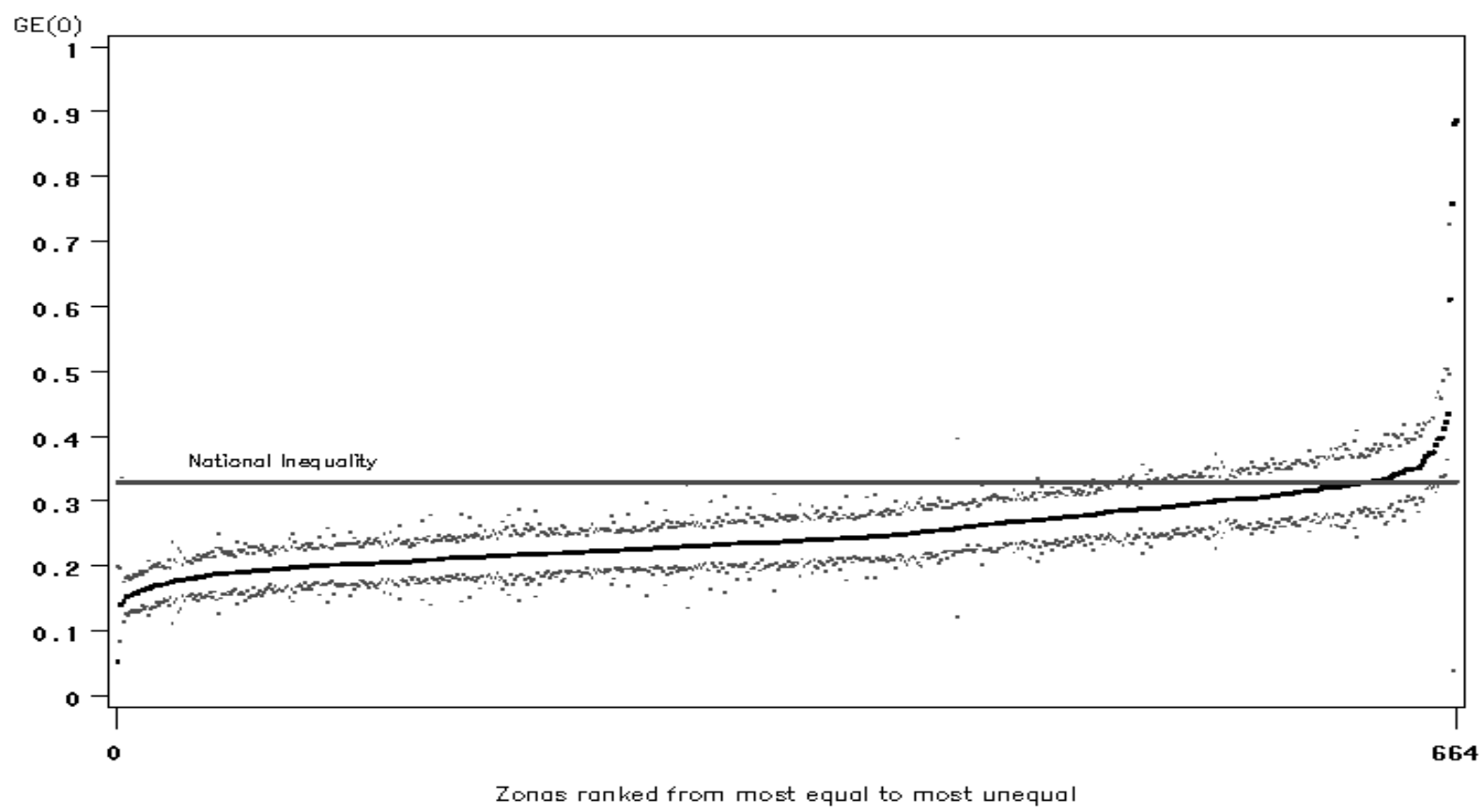




\section{Figure 3}

RURAL MADAGASCAR: Distribution Across Firaisanas of Firaisana-level Inequality: GE(o) (1117 Firaisanas; average number of households per Firaisana: 1684)

(Scatter Plot of $95 \%$ Confidence Intervals)

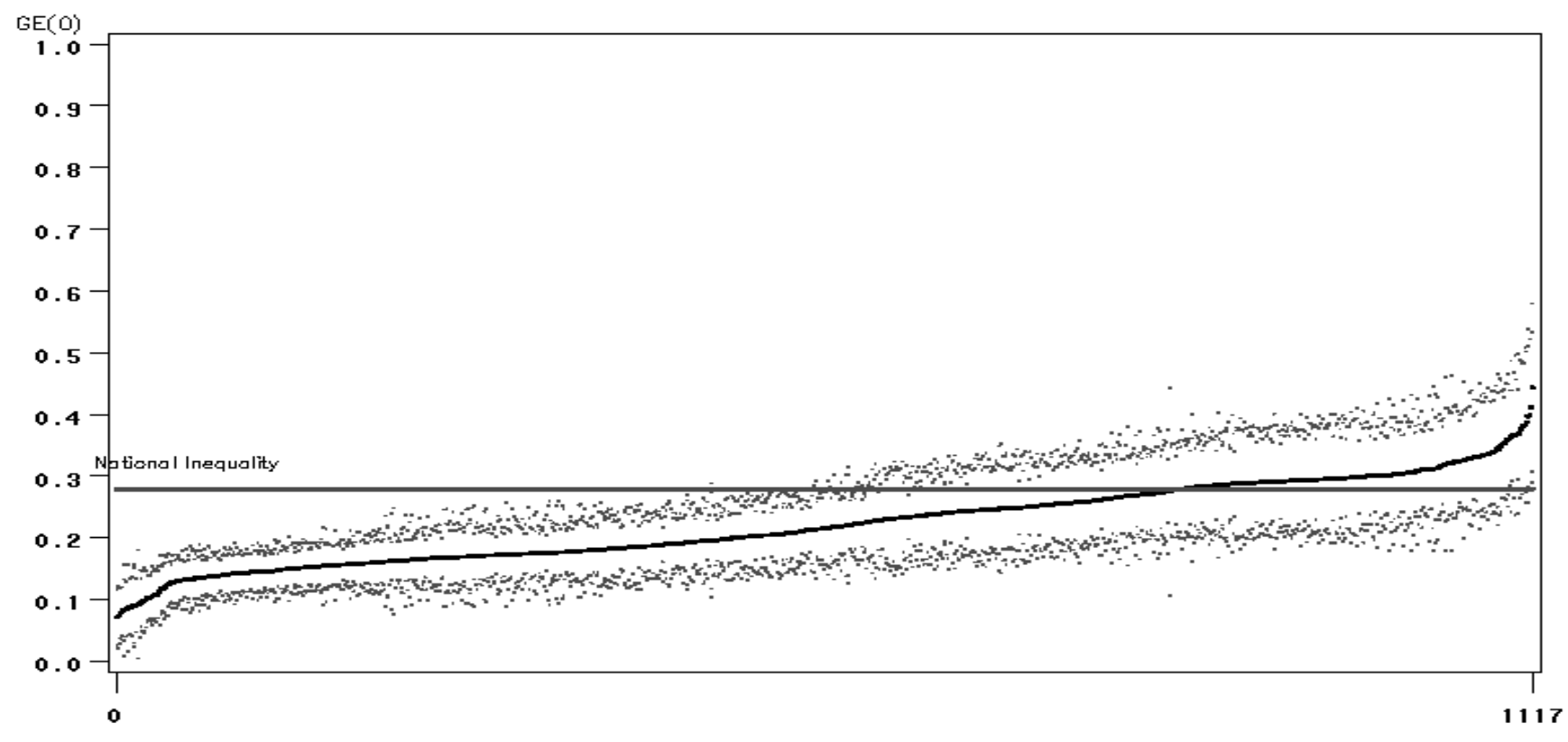

Firaisanas ranked from most equal to most unequal

\section{Figure 4}

URBAN MADAGASCAR: Distribution Across Firaisanas of Firaisana-level Inequality: GE(0) (131 Firaisanas; average number of households per Firaisana: 4190)

(Scatter Plot of $95 \%$ Confidence Intervals)

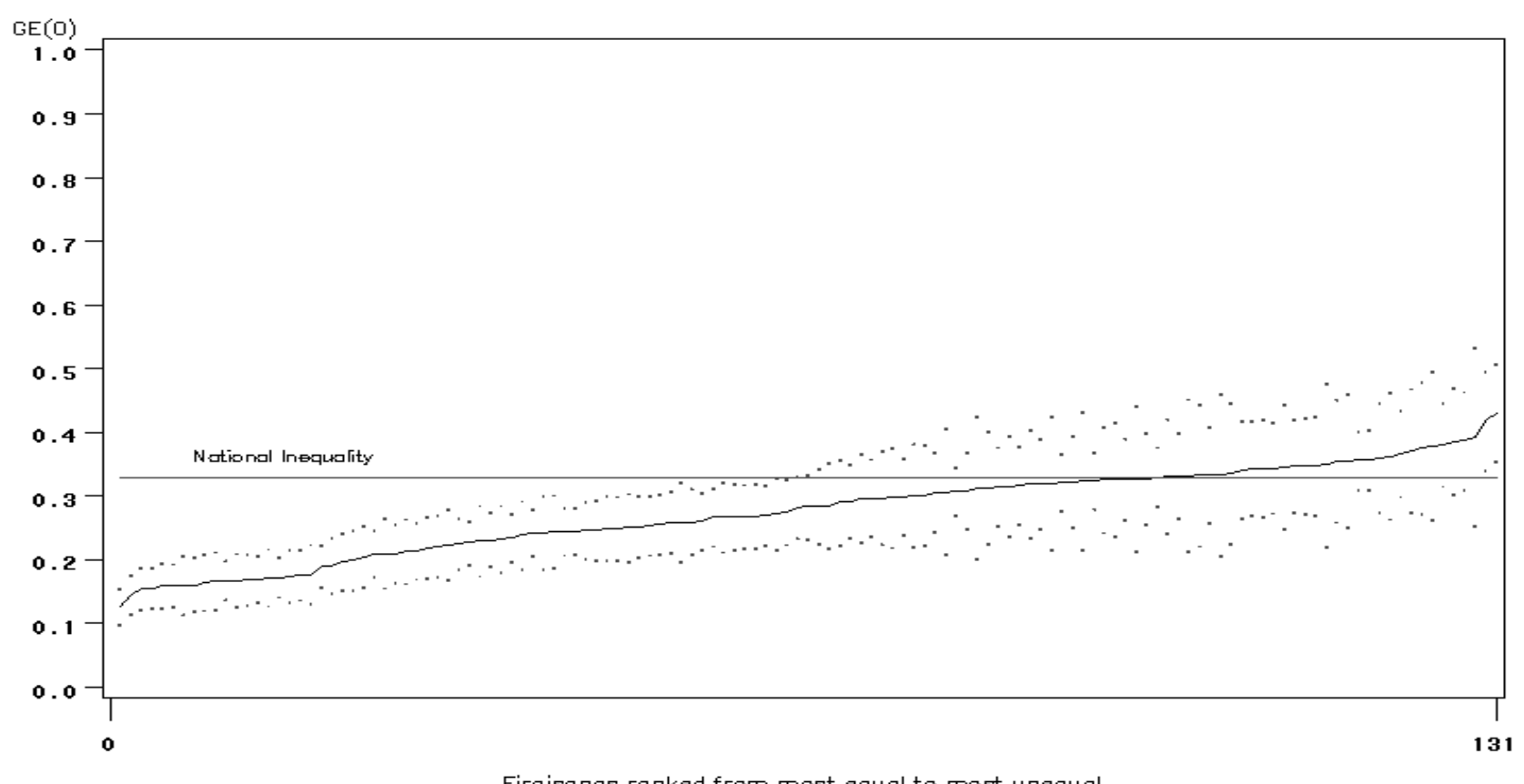

Firaisanas ranked from most equal to most unequal 


\section{Figure 5}

MOZAMBIQUE: Distribution Across Administrative Posts of Post-level Inequality: GE(0) (419 Administrative Posts; average number of households per Post: 7978)

(Scatter Plot of $95 \%$ Confidence Intervals)

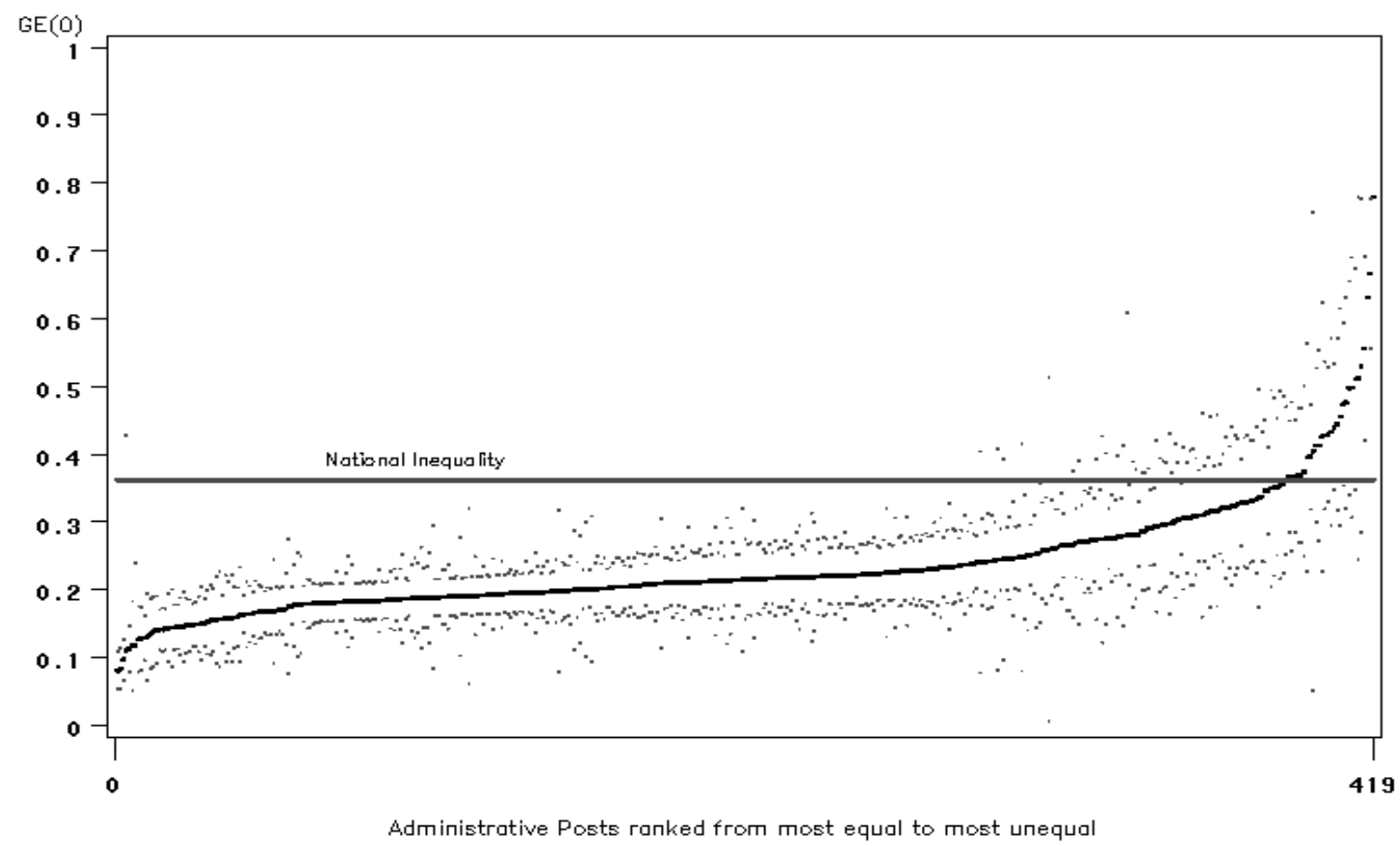


Figure 6

Unequal Inequality of Communities in Ecuador (All Communities)

Box-Whisker Percentiles: median, 25/75, 1/99

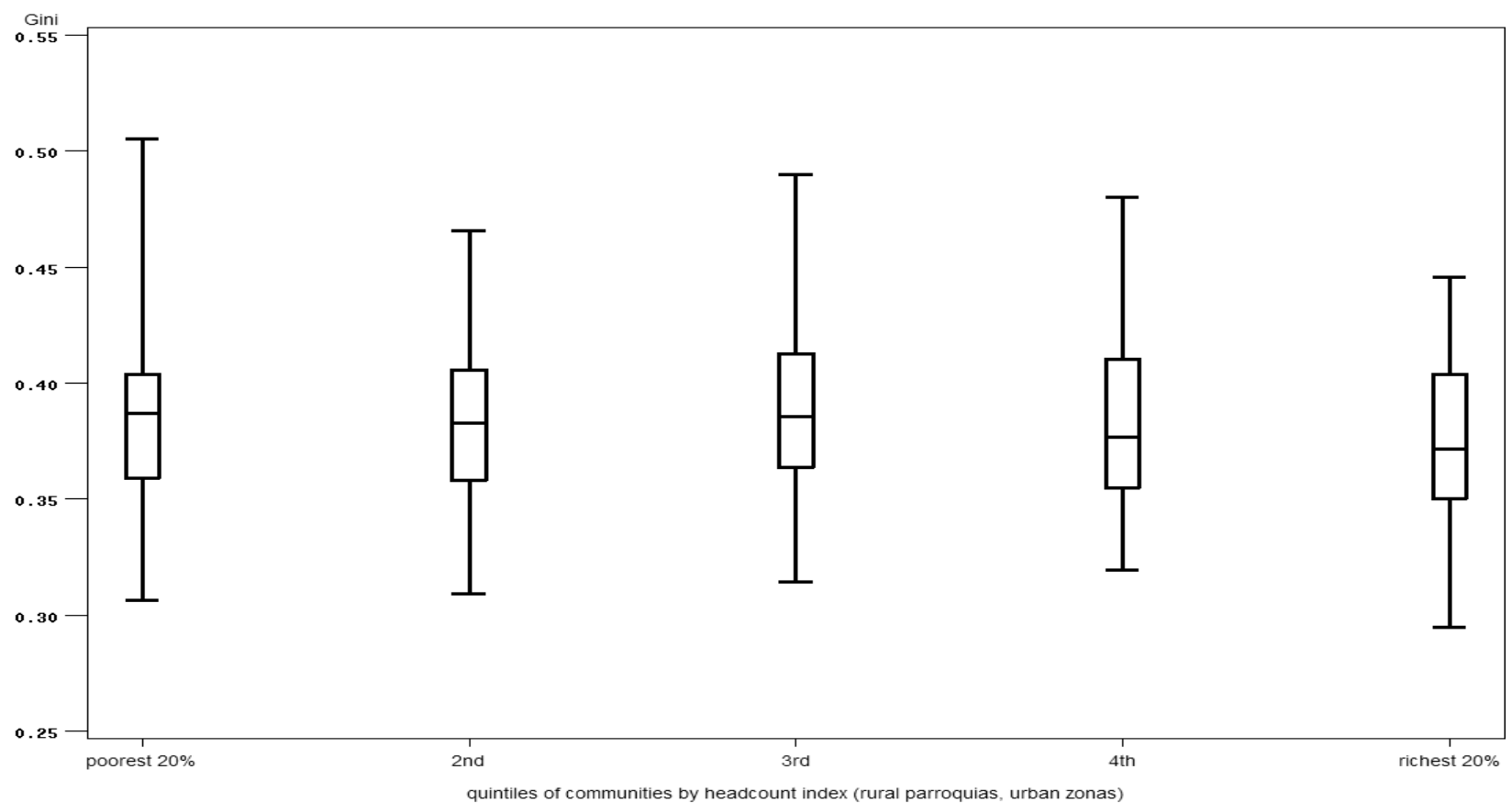

Figure 7

Unequal Inequality of Communities in Ecuador (Rural Communities)

Box-Whisker Percentiles: median, 25/75, 1/99

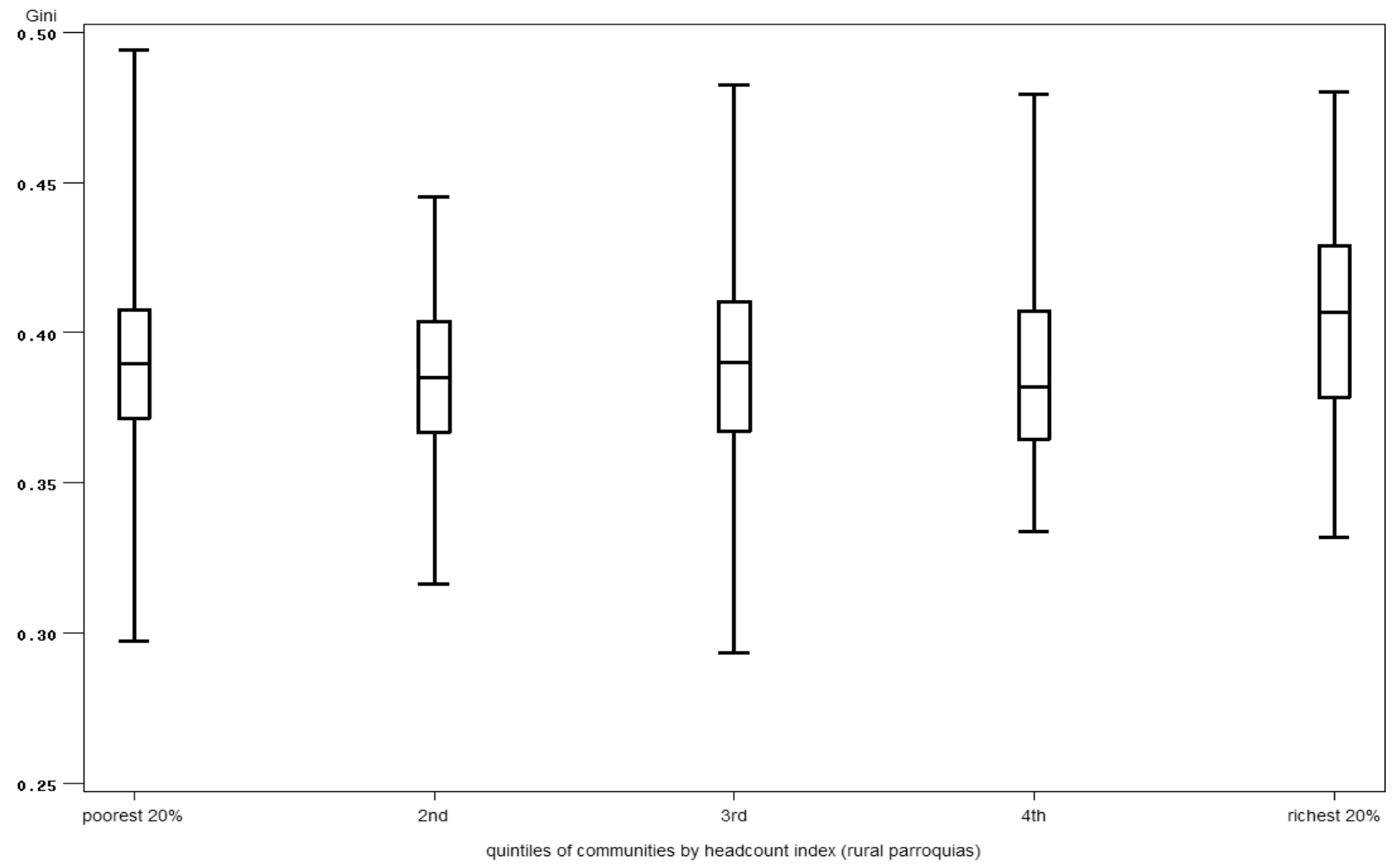


Figure 8

Unequal Inequality of Communities in Madagascar: All Communities

Box-Whisker Percentiles: median, 25/75, 1/99

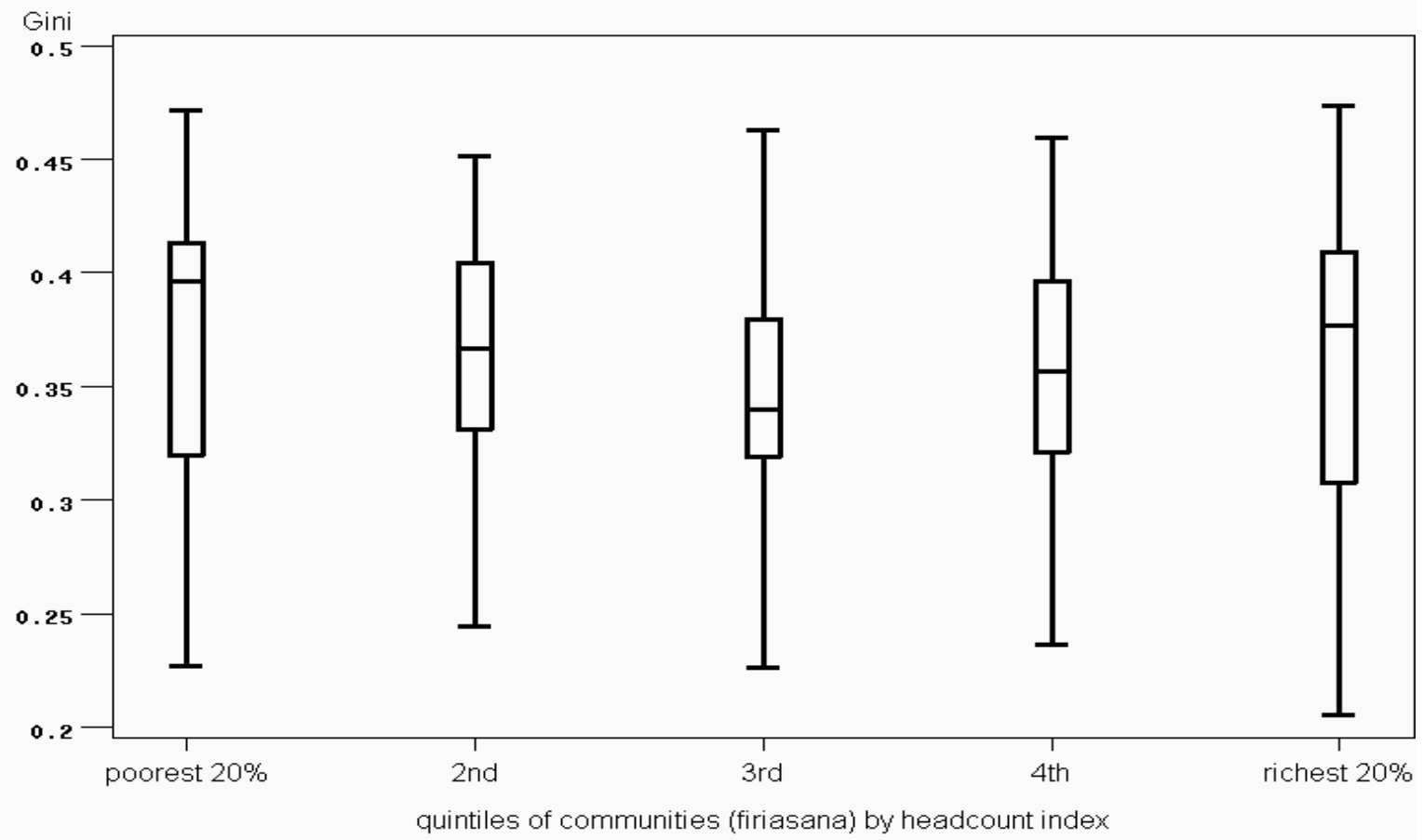

Figure 9

Unequal Inequality of Communities in Madagascar: Rural Communities

Box-Whisker Percentiles: median, 25/75, 1/99

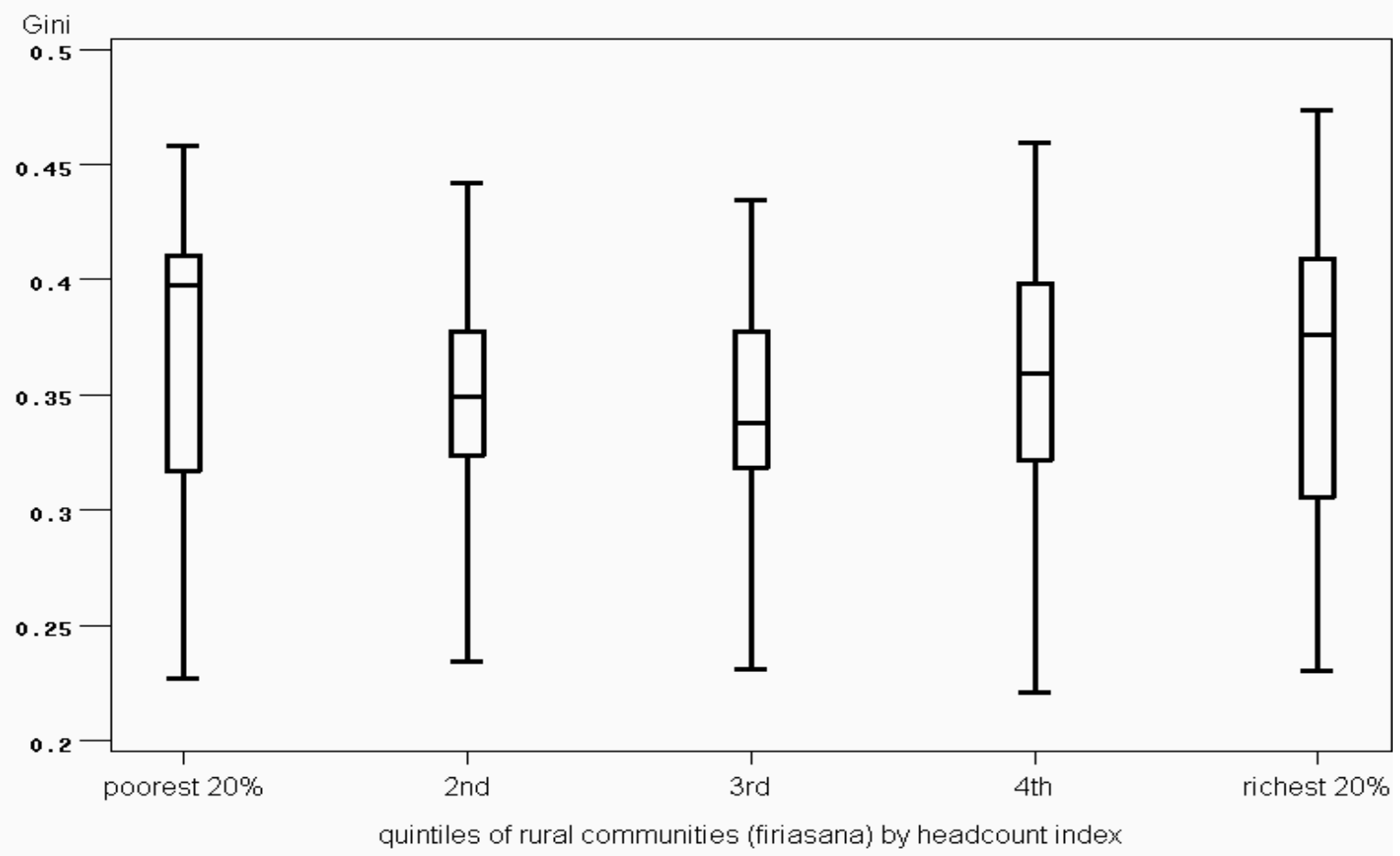


Figure 10

Unequal Inequality of Communities in Mozambique (All Communities)

Box-Whisker Percentiles: median, 25/75, 1/99

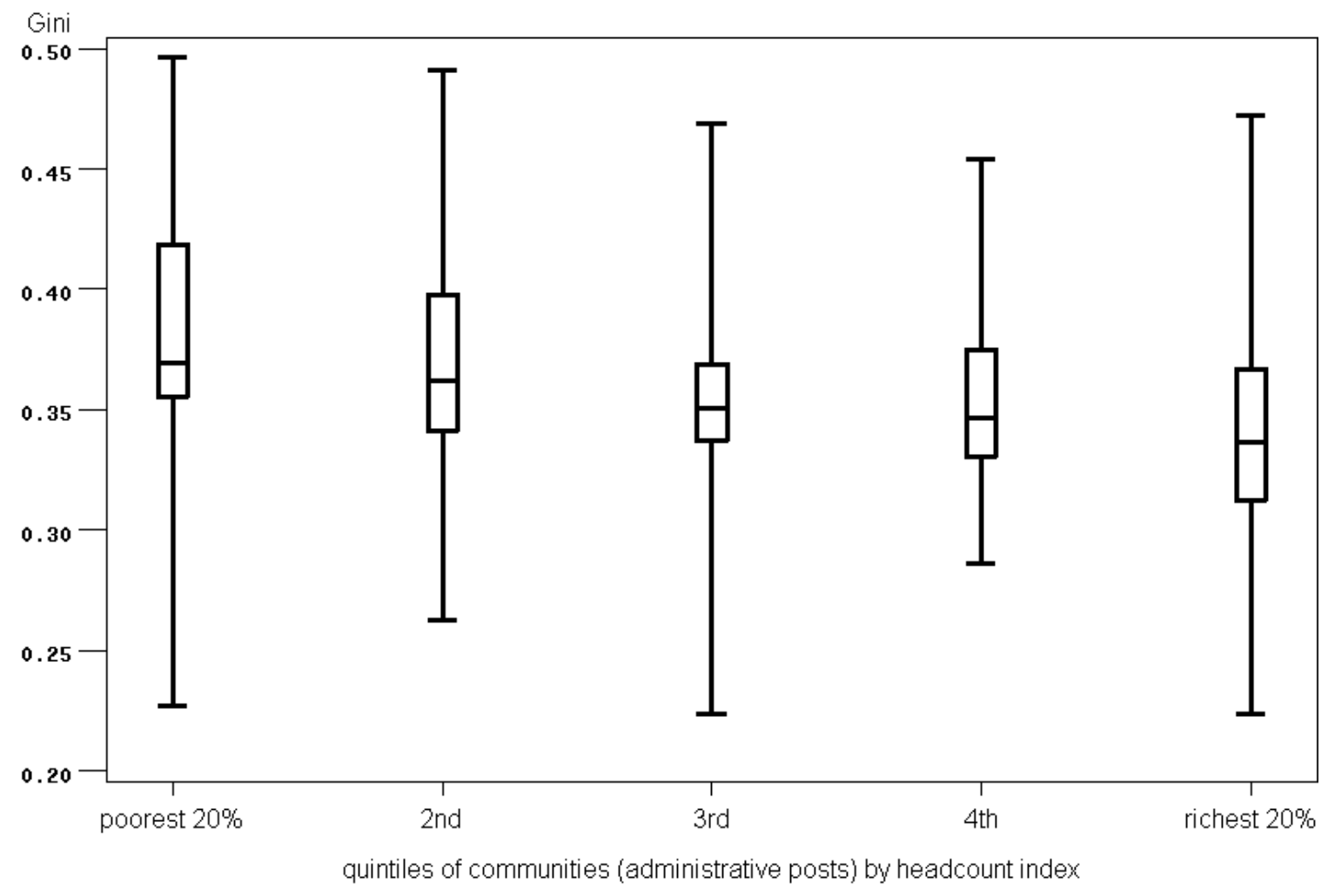

